\title{
RANCANGAN PEMBUATAN WEBSITE JURUSAN DESAIN KOMUNIKASI VISUAL (DKV) UNIVERSITAS BINA NUSANTARA
}

\author{
Danu Widhyatmoko \\ Jurusan Desain Komunikasi Visual, Fakultas Komunikasi dan Multimedia, \\ Bina Nusantara University, Jln. K.H. Syahdan No. 9, Palmerah, Jakarta Barat 11480 \\ danu@binus.edu
}

\begin{abstract}
The purpose of this article is to describe a design process of a website utilized by the Department of $D K V$, Bina Nusantara University. The website description was done by using literature methods such as analysis of similar websites, and using the website design method developed by Gene DeFazzio. From the analysis results can be obtained data classification needs and system as expected by DKV BINUS website. Then, from the data analysis, website was developed through the stages of Pre-Production, Production, and Uploading. Through this process, it has been produced a website which serves as a database and information, and supports the process of marketing and branding of the Department of DKV BINUS.
\end{abstract}

Keywords: website design, pre-production, production, uploading

\begin{abstract}
ABSTRAK
Artikel mendeskripsikan proses perancangan sebuah website yang dimanfaatkan oleh Jurusan DKV, Universitas Bina Nusantara dengan menggunakan metode studi pustaka berupa analisis terhadap website sejenis, dan menggunakan metode perancangan website yang dikembangkan oleh Gene DeFazzio. Dari hasil analisis diperoleh kebutuhan serta sistem pengelompokkan data sesuai yang diharapkan oleh website DKV BINUS. Dari data analisis tersebut dikembangkan website melalui tahapan Pre-Production, Production, dan Uploading. Lewat proses tersebut dihasilkan sebuah website yang berfungsi sebagai pusat data dan informasi serta mendukung proses marketing dan branding dari Jurusan DKV BINUS.
\end{abstract}

Kata kunci: rancangan website, pre-production, production, uploading 


\section{PENDAHULUAN}

Internet dengan teknologi informasi tidak lagi menjadi sekedar gaya hidup, beragam kemudahan dapat ditemui dengan mudah, lengkap dengan segala manfaat yang berkarakter efektif serta efisien. Informasi yang begitu banyak dan masuk berjejal membutuhkan sistem yang sederhana namun efisien pada saat mengelola, agar segala informasi tersebut dapat disalurkan secara sempurna menuju target komunikasi yang dituju. Wahana teknologi informasi ditambah dengan pendekatan desain visual yang mumpuni akan menghasilkan kombinasi yang maksimal dalam berkomunikasi, misalnya website. Rancangan Pembuatan Website Jurusan DKV Univesitas Bina Nusantara (selanjutnya disebut DKV BINUS) merupakan riset yang menghasilkan sebuah visual berupa web yang digunakan secara maksimal oleh Jurusan DKV BINUS. Website dipandang sebagai sebuah wahana efektif dan efisisen yang dapat diakses (saat ini) dengan mudah. Website bukan hanya memiliki fungsi secara administratif namun dapat menjadi representasi dari wajah Jurusan DKV BINUS. Segala informasi, baik yang bersifat akademis maupun non akademis, dapat diperoleh melalui fasilitas yang terdapat di website. Informasi tersebut dikelola menjadi sebuah database aktif yang mendukung proses pendokumentasian seluruh kegiatan dan aktivitas yang ada di DKV BINUS. Pada akhirnya web ini tidak hanya berfungsi menjadi pusat data namun juga dapat memberikan manfaat secara branding dan marketing.

Pengembangan website Jurusan DKV BINUS menggunakan 3 tahapan utama, yaitu PreProduction, Production, dan Uploading. Pada tahapan Pre-Production diperoleh hasil berupa analisis kebutuhan dari web, organisasi atau pengelompokan atas data yang ada, terbentuk pula hasil stuktur web berikut sistem navigasi dan terakhir materi isi dari web juga telah dideskripsikan. Tahapan Production terbagi menjadi tahapan Design dan Programming. Pada tahapan Design, dipilihlah Theme yang paling sesuai dengan hasil analisis, ditentukan juga layout yang sesuai, visual content yang dibutuhkan dikelompokan dan terakhir dilakukan Execution visual untuk mewujudkan web tersebut. Sedang tahapan Programming saat ini tidak lagi membutuhkan waktu yang lama karena dari hasil analisis diperoleh kesimpulan untuk menggunakan CMS WordPress, yang sangat efektif dan efisien, menjawab seluruh kebutuhan management system yang diperlukan. Setelah seluruh proses tersebut siap maka tahapan Uploading pun dilakukan.

Tujuan penelitian. Rancangan pembuatan website Jurusan DKV BINUS akan menghasilkan sebuah website yang dapat berfungsi sebagai media informasi dan komunikasi. Fungsi tersebut tentu dapat mendukung pengembangan marketing, branding, juga promosi dari DKV BINUS itu sendiri. Fungsi media informasi dan komunikasi baik internal maupun eksternal dapat terpenuhi dengan berita seputar BINUS, agenda kegiatan. Sedang untuk menjadikan pusat kelimuan DKV BINUS dapat diberikan tips seputar desain, ilmu-ilmu desain, artikel artis desain, media unjuk karya, database kegiatan, forum, online store, dan cyber gallery. Tinjauan pustaka. Berikut beberapa hasil analisis serta review dari situs sejenis. Pertama, situs www.artdes.mmu.ac.uk. Berikut adalah situs dari Manchester Metropolitan University - Faculty of Art and Design. Karakter dari institusi pendidikan di luar negeri pada umumnya membolehkan website dikelola secara penuh oleh jurusan atau fakultas, hal tersebut memungkinkan segala informasi dari pendaftaran hingga alumni dikelola lewat satu pintu jurusan/fakultas, termasuk situs resmi mereka. Karakter tersebut sedikit berbeda dengan BINUS University, pengelolaan situs dilakukan secara terpusat oleh universitas.

Hal menarik yang ditemui pada situs ini adalah segala informasi dapat ditemui dengan mudah, baik informasi mengenai pendaftaran hingga aktivitas keseharian mereka (baik akademis maupun non akademis). Berita seputar kegiatan mereka disajikan menurut standar publikasi yang baik. Ruang galeri mereka juga turut diinformasikan secara komprehensif, lewat halaman galeri yang terpisah, hingga para pengunjung dapat fokus menikmati serta mengapresiasi hasil karya para akademisi dari institusi tersebut. Koleksi, jadwal pameran dan sejarah galeri tersebut disajikan dengan baik dan mudah dalam pencarian. Kolaborasi antar institusi seni dan desain turut disajikan, termasuk kolaborasi 
mereka dengan pemerintah kota. Riset juga mendapat porsi tersendiri di situs tersebut. Secara visual, situs ini menggunakan pendekatan dua kolom utama. Tampilan yang bersih dan sederhana, dengan layout yang tetap tak berubah memungkinkan para pengunjung mudah dalam melakukan navigasi serta pencarian.

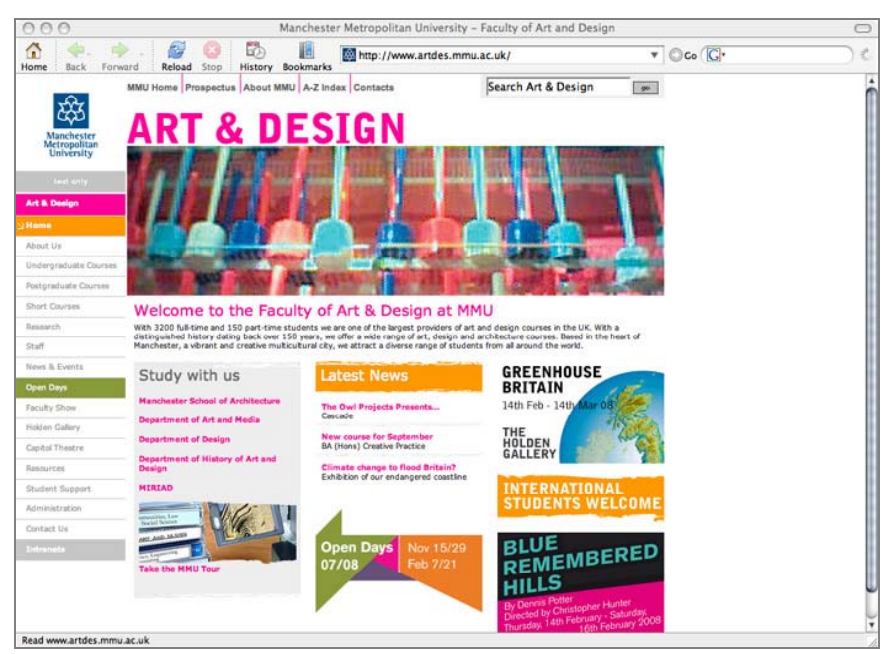

Gambar 1 Situs Faculty of Art and Design - Manchester Metropolitan University (Sumber: screen capture dari www.artdes.mmu.ac.uk)

Kedua, Situs www.ucreative.ac.uk. Berbeda dengan situs Faculty of Art and Design MMU, maka situs dari University for The Creative Arts ini menitikberatkan pada kemudahan shortcuts - juga scripting pada mesin pencari (sisi kanan atas - course finder dan site search). Fasilitas shortcuts yang menarik dari situs ini adalah kemudahan untuk langsung berinteraksi dengan institusi terkait, interaksi tersebut berupa shortcuts "ask UCA" juga "order a Prospectus". Guna memperlihatkan hasil contoh karya dari institusi tersebut turut dibuatkan shortcut menuju galeri online mereka, "UCA showcase". Sedang informasi yang bersifat umum, seputar institusi, disajikan terpusat di sisi kiri. Secara umum, situs UCA disajikan dengan sederhana dengan tampilan visual situs standar. Kemudahan pencarian/navigasi menjadi penekanan mereka, untuk itulah fungsi shortcuts menjadi prioritas mereka untuk tampil di halaman utama situs mereka.

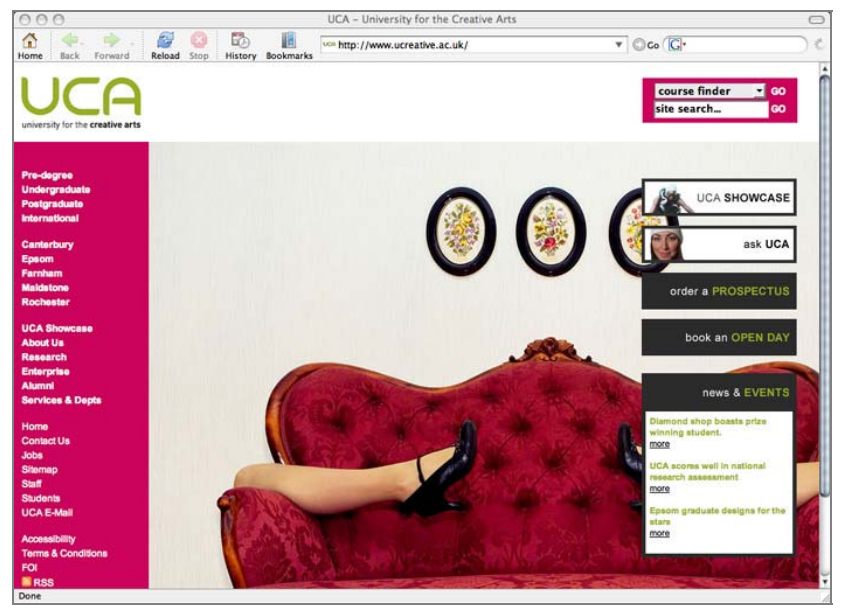

Gambar 2 Situs University for The Creative Arts (Sumber: screen capture dari www.ucreative.ac.uk) 


\section{METODE PENELITIAN}

Metode yang digunakan dalam membangun sebuah website relatif tidak terlalu berbeda antara satu metode dengan metode yang lain. Pada pengembangan website DKV BINUS ini yang digunakan adalah metode yang ditulis oleh Gene DeFazzio, metode tersebut dipublikasikan lewat www.RocketFace.com. Berikut struktur metode tersebut:

Tabel 1 Bagan Kerja Metode Pengembangan Situs oleh Gene DeFazzio

(Sumber: www.RocketFame.com)

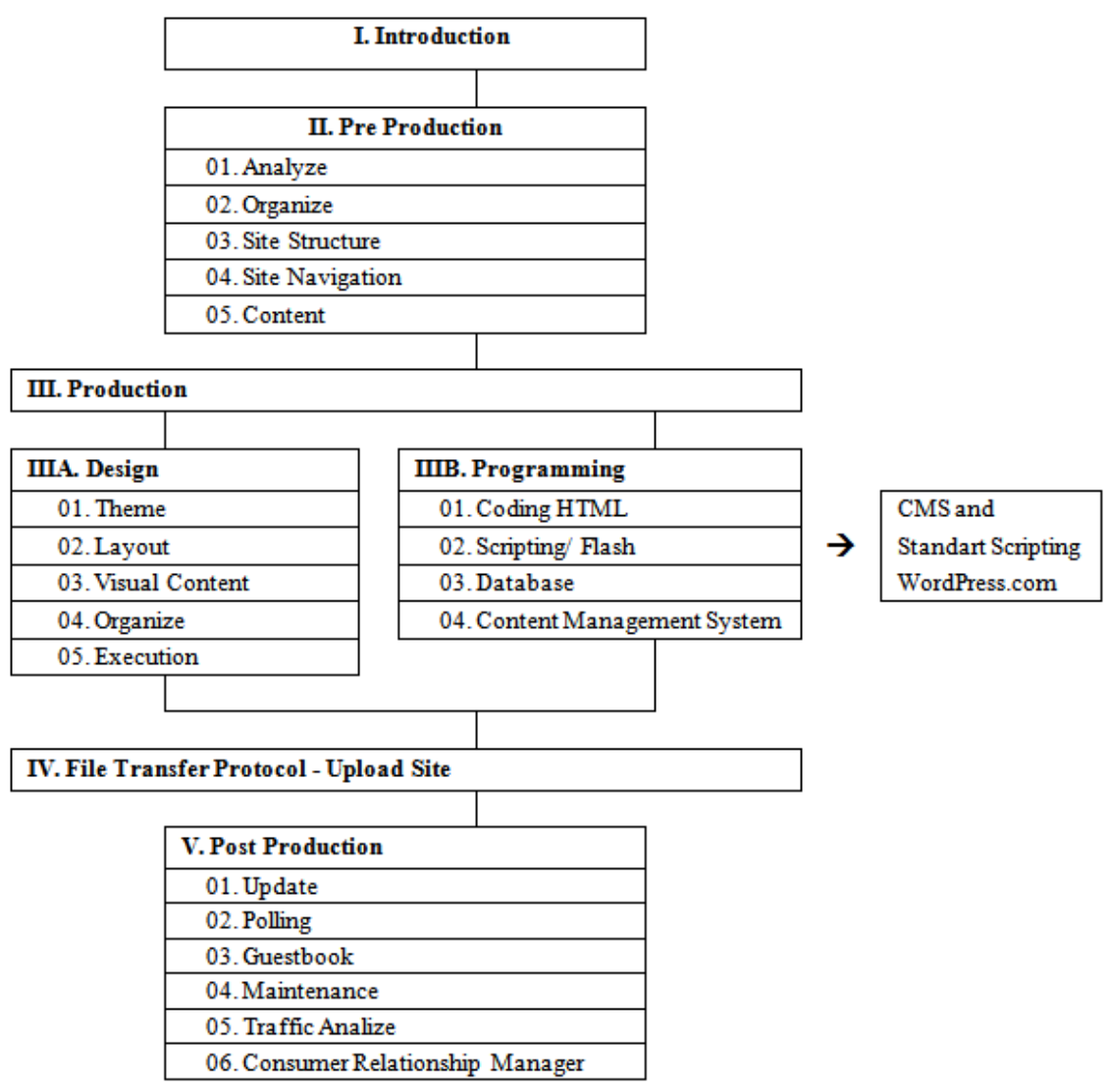

HASIL DAN PEMBAHASAN

\section{Pre Production}

Pada tahapan ini, dimulai dengan melakukan analisis terhadap kebutuhan website DKV BINUS dengan tujuan dapat dipetakan berdasarkan fungsi sebagai media informasi dan pusat data yang mendukung aktivitas marketing dan branding. Pada analisis content sebuah website jurusan dikembangkan menjadi pusat informasi, baik eksternal maupun internal. Jenis informasi dari internal yang dikomunikasikan ke luar seperti seputar aktivitas pembelajaran, kegiatan-kegiatan, informasi mendasar dari sebuah institusi, prestasi, karya dan obyek kreativitas yang dapat dijual baik itu barang dan jasa yang dikelola oleh internal. Jenis informasi dari eksternal yang dikomunikasikan ke dalam seperti seputar kegiatan-kegiatan kreatif yang diadakan di luar, baik itu workshop, seminar, beasiswa, pameran juga lomba. 
Agar informasi tersebut dapat diterima oleh internal DKV BINUS dan dapat segera dimanfaatkan. Sedang sebagai pusat keilmuan DKV, galeri karya disiapkan untuk menampung karya yang dilengkapi dengan proses dan konseptual, namun sudah tentu harus disesuaikan dengan karakter dari tugas yang diberikan. Selain itu tutorial dan tips seputar keilmuan DKV juga dapat dikembangkan, lebih yang bersifat teknis dan praktis. Dan terakhir dapat disertakan juga pemikiranpemikiran seputar keilmuan DKV yang dituangkan dalam bentuk Jurnal (penulisan ilmiah) ataupun artikel popular. Pada analisis target, website jurusan DKV BINUS itu memiliki target internal meliputi dosen, mahasiswa, alumni dan binusian. Target eksternal meliputi calon mahasiswa, masyarakat, dan industri DKV. Sedang secara psikografi, website terkait diperuntukkan kepada penikmat dan pemerhati DKV. Struktur yang dikembangkan di web DKV BINUS menggunakan 2 struktur, yaitu homepage dan insidepage (Gambar 3 dan 4).

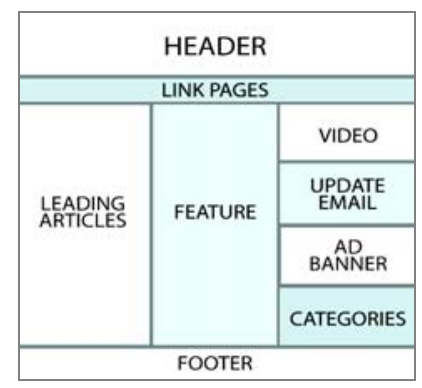

Gambar 3 Struktur Halaman Depan (Homepage)

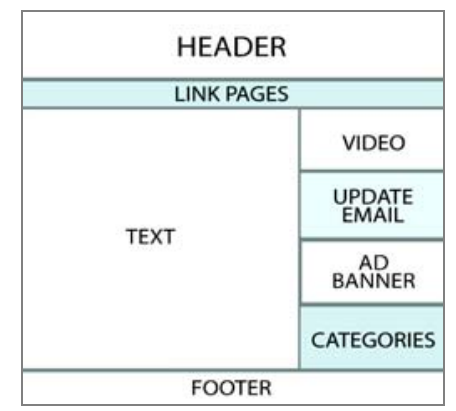

Gambar 4 Struktur Halaman Dalam (Insidepage)

Header, berisi nama situs dan visual tematik, header ini senantiasa berada di bagian atas situs, sebagai penjaga keseragaman. Link Pages, berisi link seluruh pages utama yang ada di situs. Leading Articles, cerita/artikel/berita utama yang sedang dikomunikasikan. Featured, berisi kategori-kategori utama yang ingin ditonjolkan dan bersifat popular dan menjual. Video, tampilan video. Update Email, fasilitas untuk para pengunjung yang ingin mendapatkan update email secara berkala dari situs. Selain itu juga terdapat tombol RSS Feed dengan fungsi yang relatif sama namun berbeda secara media. $A D$ Banner, fasilitas banner iklan, dapat juga berfungsi sebagai media saling bertukar link dengan situs lain. Categories, fasilitas pencarian artikel/cerita/berita berdasarkan kategori. Text, ruang tampilan yang berisi teks artikel/cerita/berita. Dua tampilan dasar yang digunakan membantu dalam sistem navigasi, para pengunjung menjadi mudah dan terbiasa untuk mencari dan memanfaatkan link serta fasilitas yang ada di dalam situs.

Fungsi dari navigasi website (site navigation) adalah membantu para pengunjung untuk lebih mudah dan cepat dalam mendapatkan informasi. Metode navigasi yang digunakan di situs ini adalah Navigasi berdasarkan hirarki (berawal dari sesuatu yang umum lalu mendetail ke hal yang khusus), 
Hierarchichal Navigation. Navigasi ini dimunculkan dalam link pages. Lalu, untuk menambah kemudahan dalam navigasi, ditambahkan dengan pendekatan berdasarkan kategori (categories), berupa link yang mengelompokkan tiap artikel/berita/cerita berdasarkan kategori. Hingga apabila kita memiliki salah satu link dari kategori tersebut, maka akan muncul artikel/berita/cerita dalam kategori yang sama. Short cuts, pada halaman depan dimunculkan dalam bentuk Leading Articles, Featured dan Movie/Video.

Tabel 2 Site Architecture www.dkv.binus.ac.id

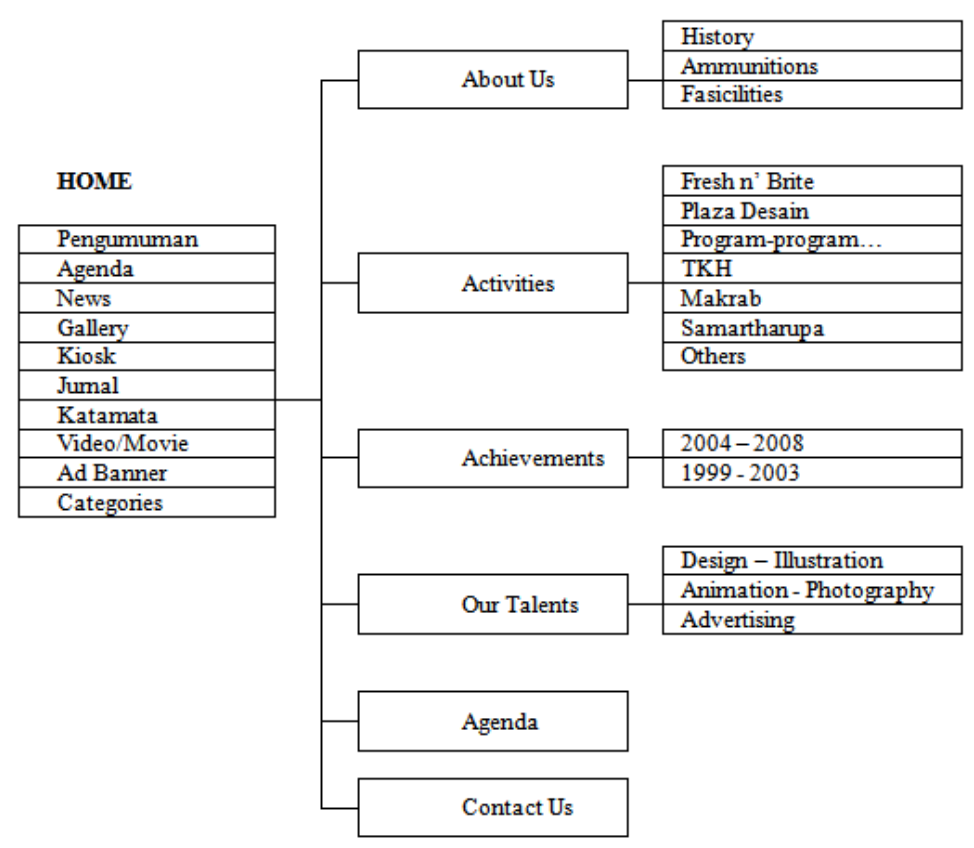

Deskripsi dari masing-masing pages, yaitu (1) Pengumuman, digunakan untuk memberikan pengumuman baik yang bersifat internal maupun yang berasal dari luar DKV BINUS; (2) Agenda, berisi jadwal/tanggal berlangsungnya kegiatan-kegiatan yang dilaksanakan oleh DKV BINUS; (3) News, berisi informasi mengenai kegiatan-kegiatan yang dilakukan oleh jurusan, universitas maupun himpunan; (4) Gallery, tampilan yang berada di halaman depan situs berfungsi sebagai shortcut -featured, menampilkan sedikit (preview) dari karya hasil tugas mahasiswa. Sedang gallery sendiri dikelola secara terpisah, dengan struktur visual yang lebih sesuai dengan kebutuhan gallery online itu sendiri. Materi yang ditampilkan dilengkapi dengan brief serta konsep perencanaan, kecuali untuk tugas-tugas yang masih bersifat teknis; (5) Kiosk, seperti gallery, fungsi dasar di halaman depan adalah sebagai shorcut -- featured. Ke depan kiosk dibuat terpisah, mengakomodasi karya dari mahasiswa, dosen, alumni yang bersifat ekonomis, memungkinkan untuk dijual. Pengelolaan kiosk ini ditangani oleh jurusan dan himpuan, dilengkapi dengan identitas visual yang lengkap; (6) Jurnal, berisi kumpulan penulisan ilmiah yang berasal dari Jurnal Aksen (internal DKV BINUS) dan tulisan dosen DKV BINUS di Jurnal luar; (7) Katamata, tulisan bersifat artikel popular; (8) Video, video/film yang diproduksi oleh DKV BINUS; (9) Ad Banner, fasilitas banner iklan, dapat juga berfungsi sebagai media saling bertukar link dengan situs lain; (10) Categories, Fasilitas pencarian artikel/cerita/berita berdasarkan kategori; (11) About us, informasi seputar institusi, sumber daya, fasilitas, visi-misi; (12) Activities, dokumentasi kegiatan-kegiatan yang telah dilaksanakan oleh DKV BINUS semenjak DKV BINUS berdiri; (13) Achievements, penghargaan, kemenangan serta prestasi yang telah dicapai; (14) Our Talents, fasilitas untuk merangkum seluruh Binusian DKV BINUS, agar tercipta jaringan keilmuan dan profesi yang baik berdasar kompetensi; (15) Contact us, fasilitas untuk menghubungi DKV BINUS secara langsung. 


\section{Production}

Di dalam pengembangan (tahap production), sebuah website selalu terbagi menjadi 2 tahapan besar, yaitu desain dan programming.

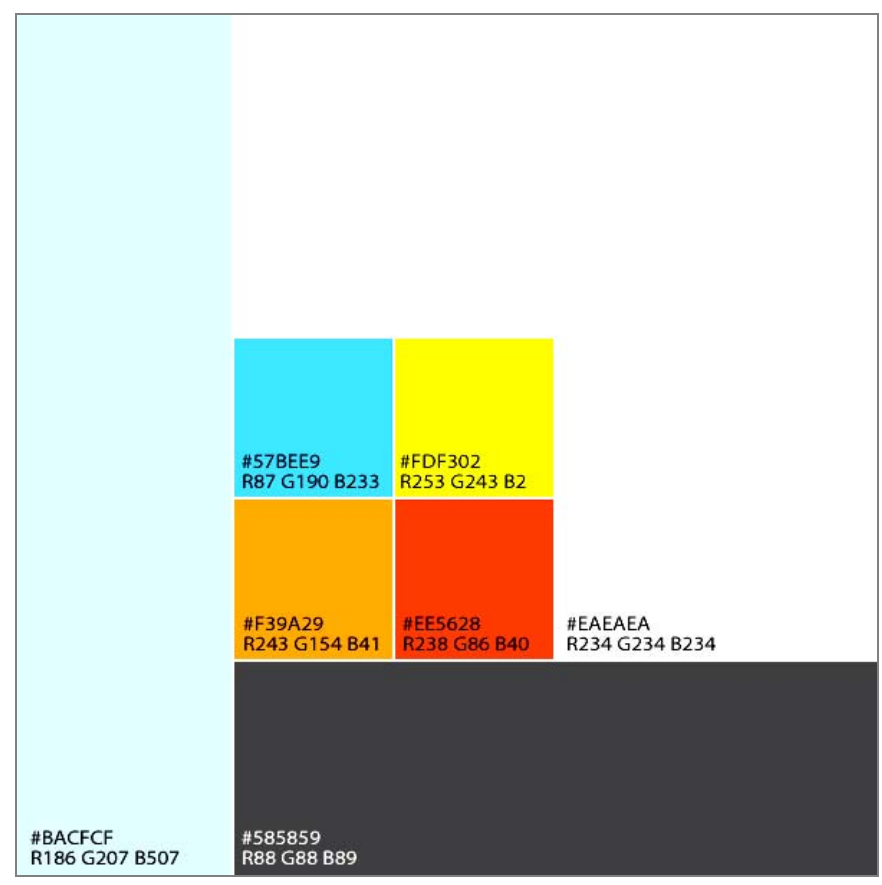

Gambar 5 Skema Warna Situs DKV BINUS

Situs DKV BINUS menggunakan skema warna yang sedang dipergunakan oleh Jurusan. Untuk mendapatkan keterkaitan dan kesinambungan antara materi-materi visual yang digunakan oleh DKV BINUS maka situs ini pun memilih untuk menggunakan skema warna tersebut. Begitu pun dengan theme visual yang digunakan, menggunakan elemen visual yang telah dikembangkan oleh DKV BINUS. Elemen visual yang dimanfaatkan sebagai visual header tersebut didesain oleh Dimas Raditya lalu didesain kembali oleh Joneta Witabora.

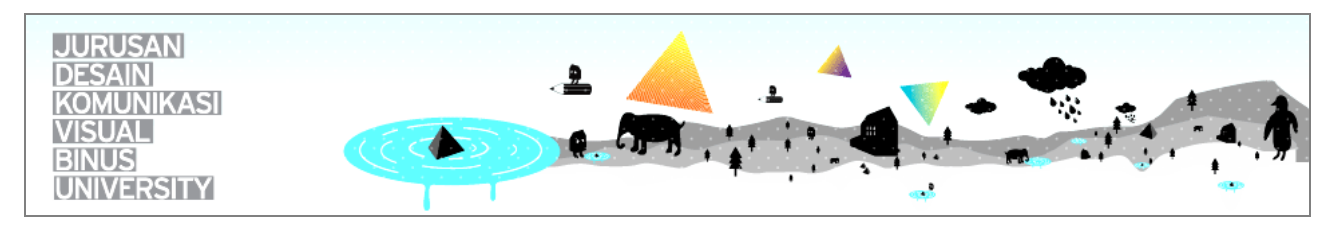

Gambar 6 Header Awal - Desain oleh Dimas Raditya

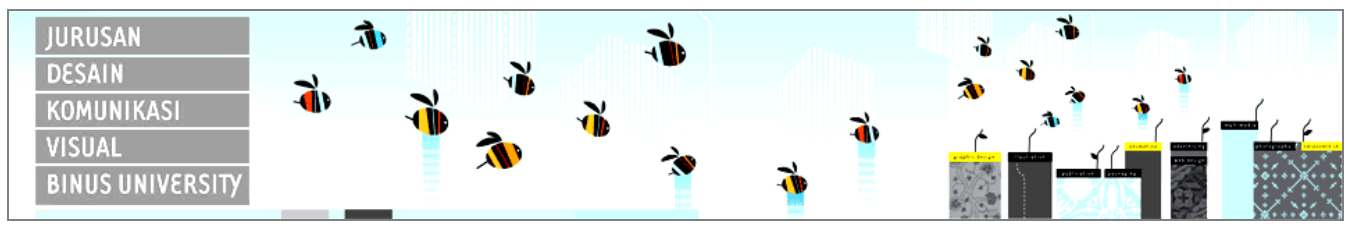

Gambar 7 -- Header - Desain oleh Joneta Witabora 
Mengenai layout, pada saat awal template desain yang digunakan adalah template web blog dengan type magazine. Template tersebut didesain awal oleh RevolutionTheme.com . Lalu diolah kembali baik script, CSS maupun elemen desainnya.

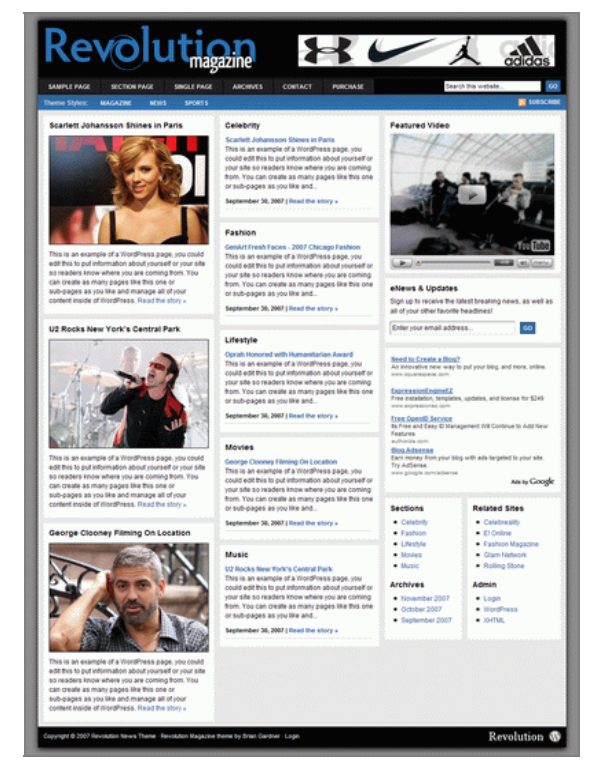

Gambar 8 Template Awal oleh RevolutionTheme.com (Sumber: screen capture dari www.RevolutionTheme.com)

Bentuk dasar dari template awal yang dimiliki oleh RevolutionTheme memiliki lebar 960 pixels, memiliki lebar yang tetap, tidak bergerak mengikuti lebar dari tampilan browser, align tengah (center align), latar menggunakan warna \#EAEAEA (R234 G234 B234), memiliki ukuran tinggi header setinggi 155 pixels, ukuran tiap kolom (terdapat 3 kolom) selebar 320 pixels, memiliki ukuran tampilan video sebesar 300 × 250 pixels, dan ukuran masing-masing ad-banner sebesar $298 \times 60$ pixels.

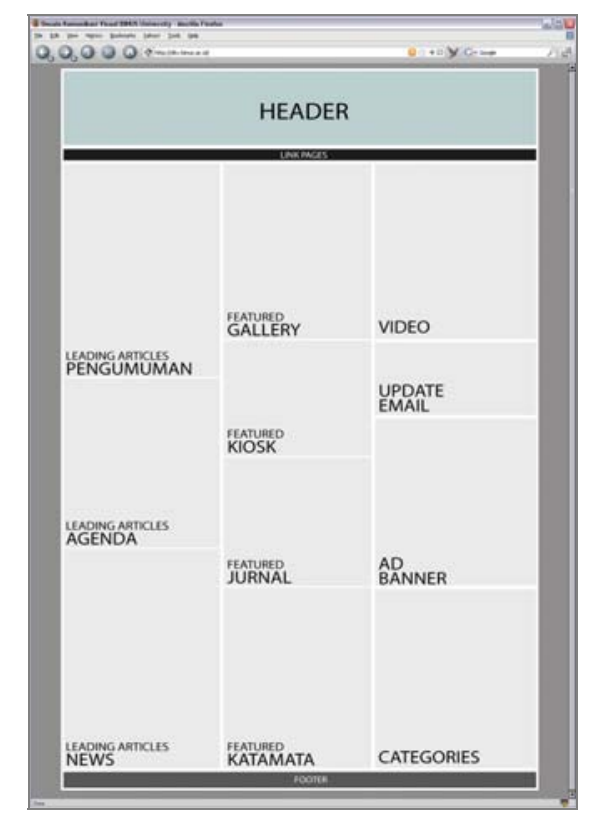

Gambar 9 Layout Halaman Depan dari Situs DKV BINUS 


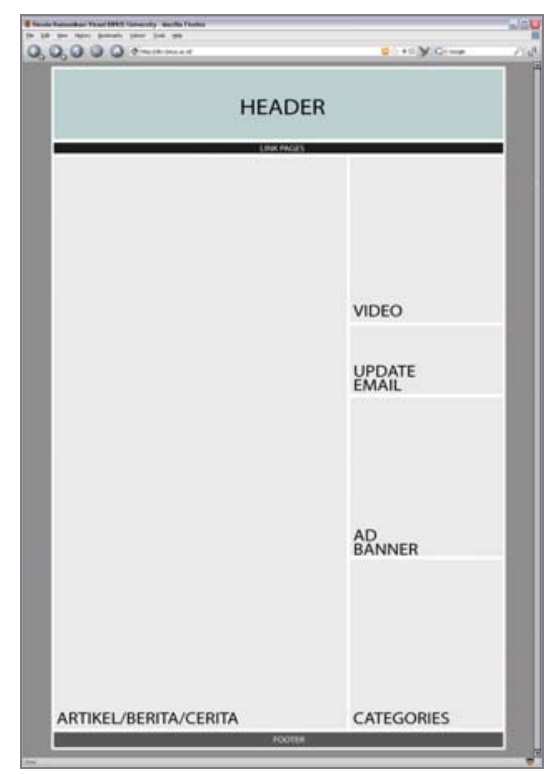

Gambar 10 Layout Bagian Dalam dari Situs DKV BINUS

Melengkapi content of visual yang dimiliki oleh website DKV BINUS, maka website ini menggunakan jenis huruf standar yang dimiliki oleh tiap Operating System komputer yang ada, yaitu font-family dari Trebuchet MS, Verdana, Tahoma, Arial. Hal ini dipilih untuk memudahkan para pengunjung untuk mengakses website DKV BINUS secara lintas browser ataupun lintas operating system. Sebagai hasil akhir dari eksekusi tampilan visual dari website DKV BINUS, ditampilkan sebagai berikut:

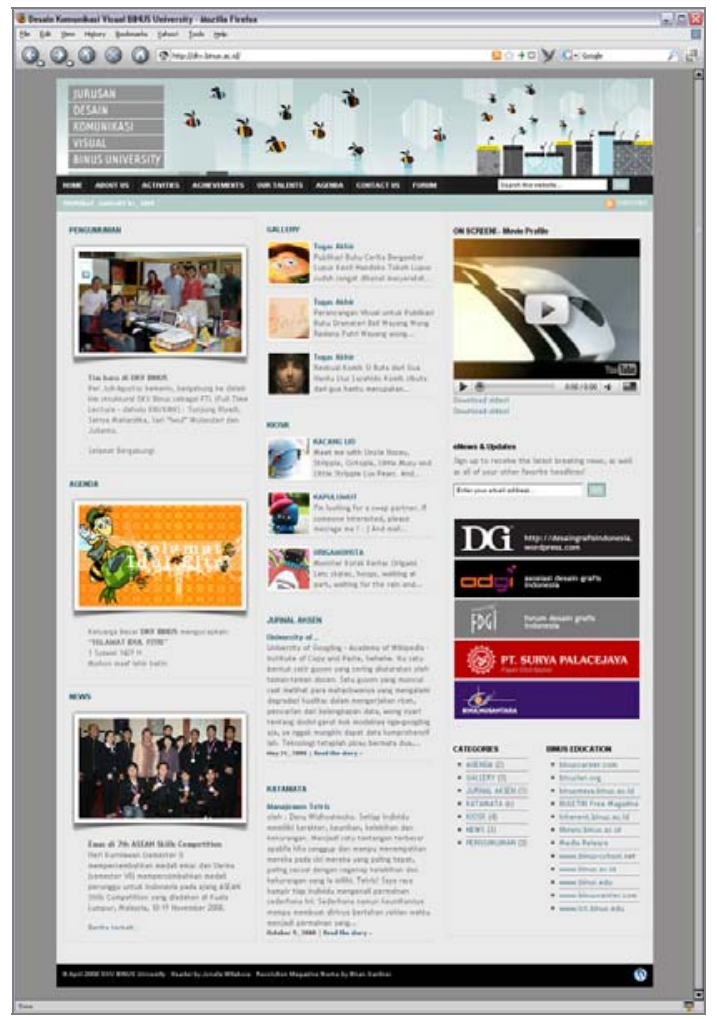

Gambar 11 Tampilan Halaman Depan dari Situs DKV BINUS 


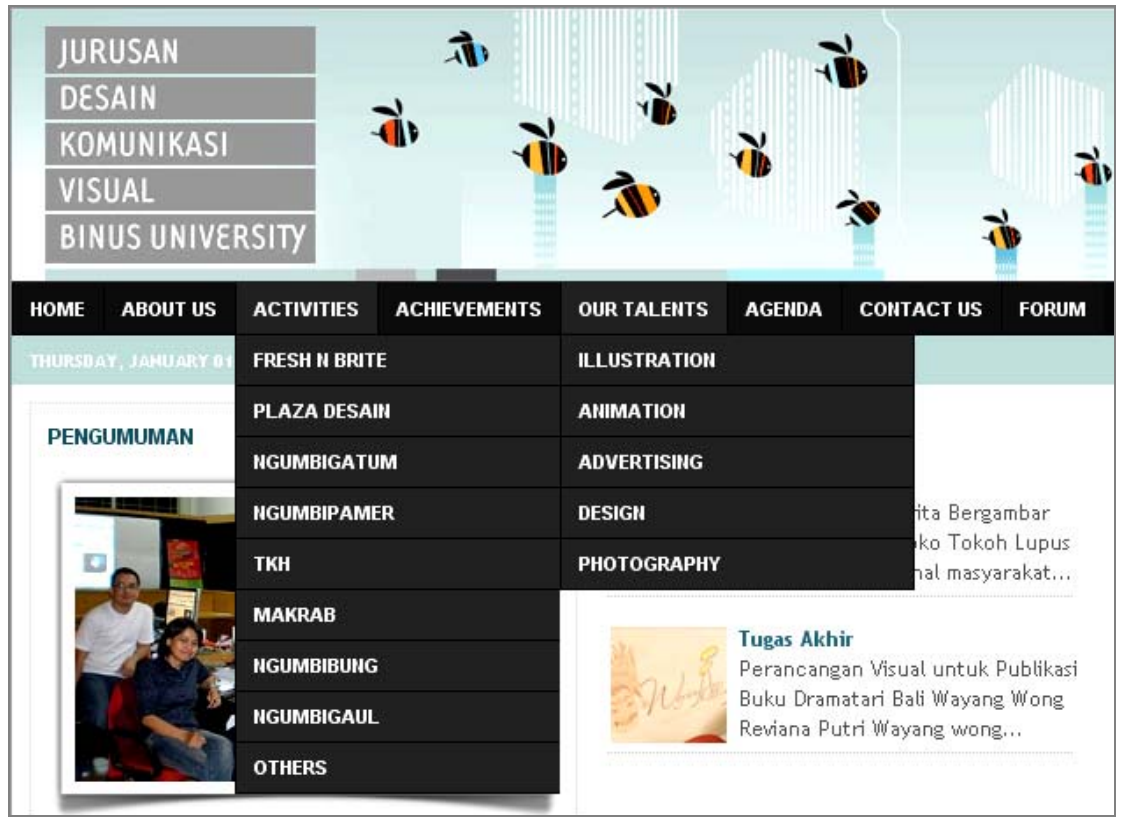

Gambar 12 Tampilan Penempatan Link Pages dan Sub Pages dari Situs DKV BINUS

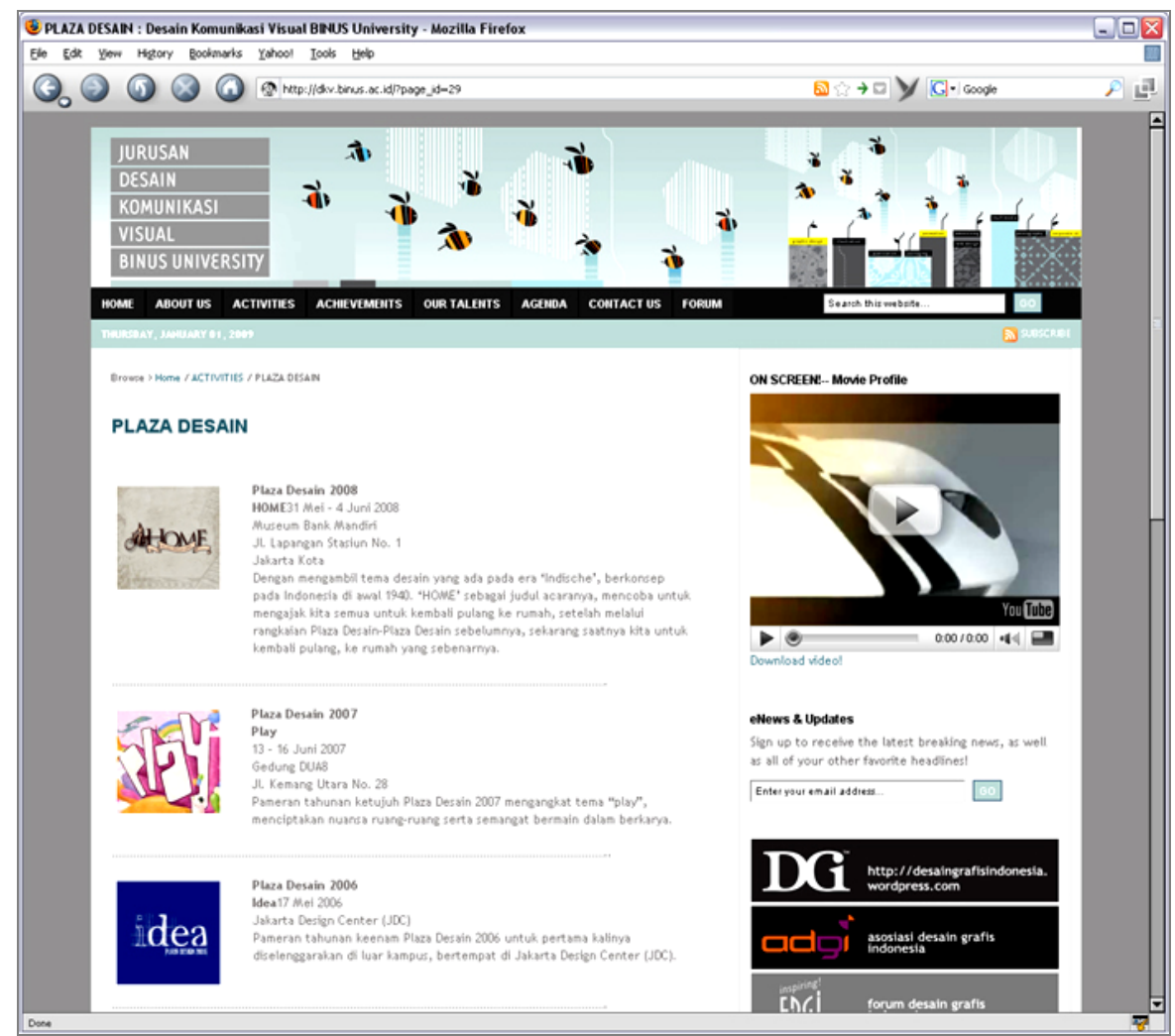

Gambar 13 Salah Satu Tampilan Halaman Dalam dari Situs DKV BINUS - Activities | Plaza Desain 


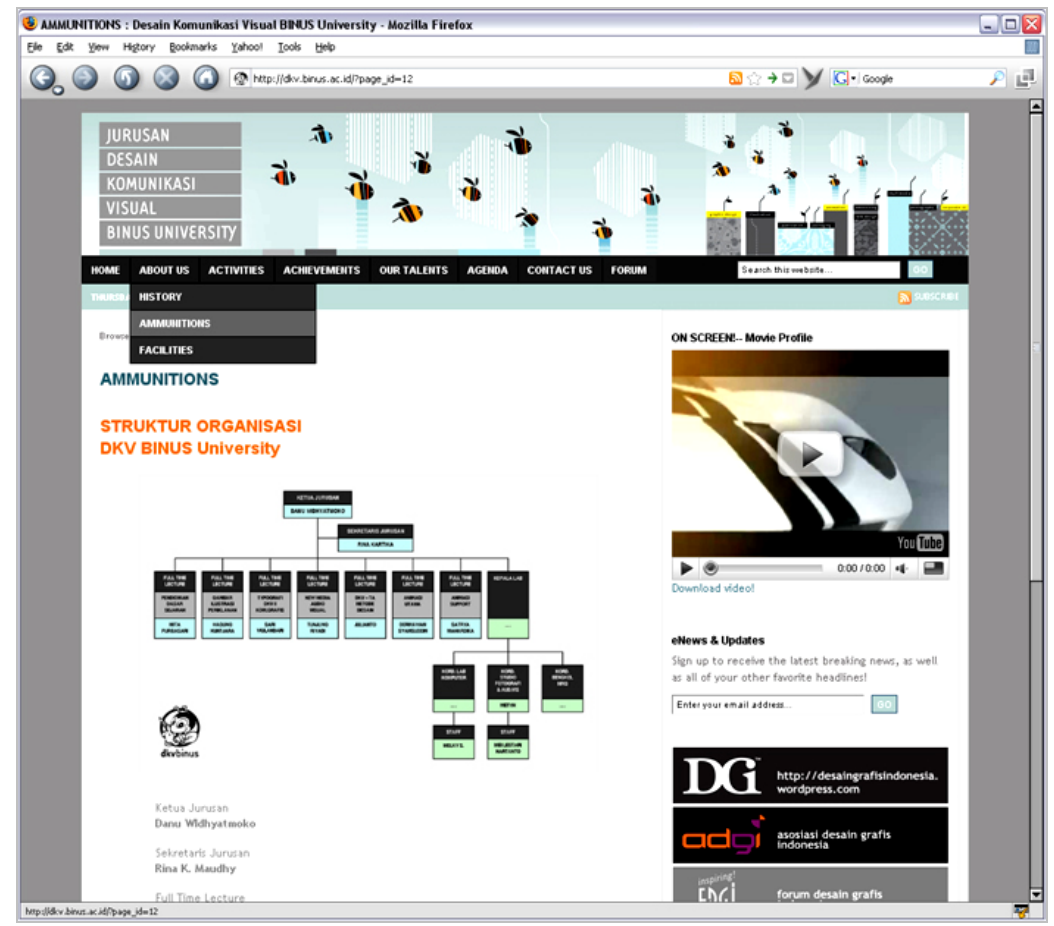

Gambar 14 Salah Satu Tampilan Halaman Dalam dari Situs DKV BINUS - About Us | Ammunitions

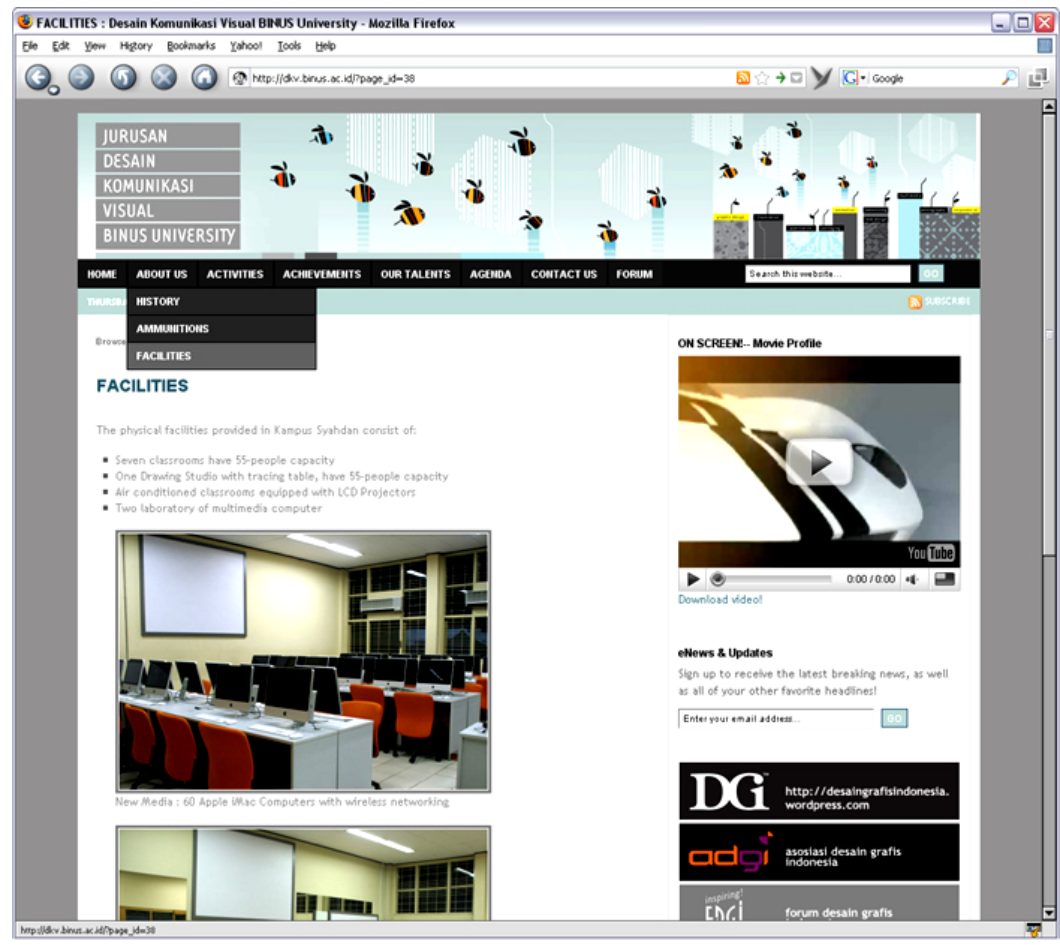

Gambar 15 Salah Satu Tampilan Halaman Dalam dari Situs DKV BINUS - About Us | Facilities 


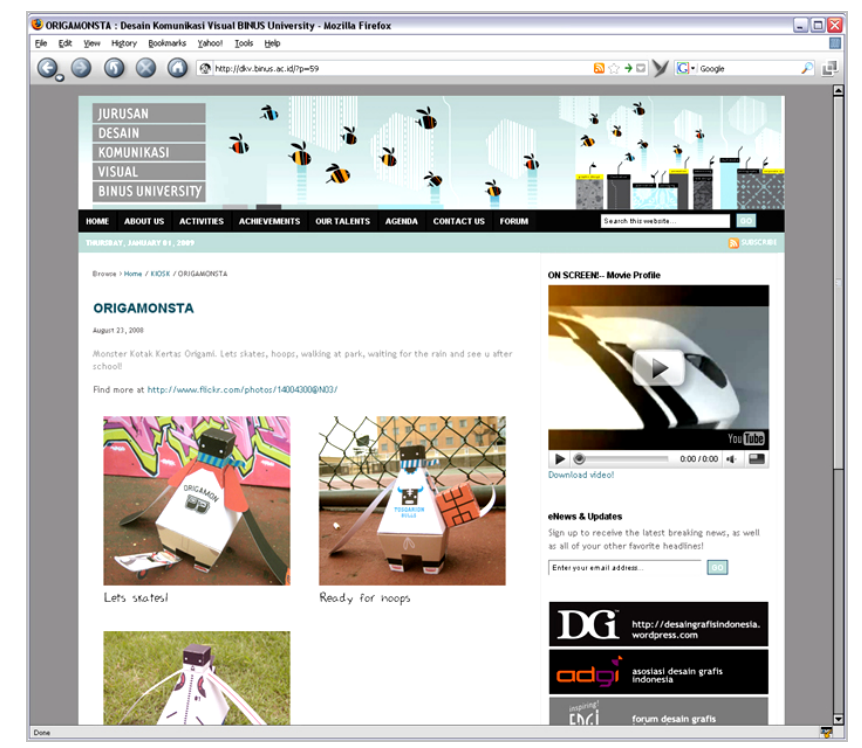

Gambar 16 Salah Satu Tampilan Halaman Dalam dari Situs DKV BINUS - Kiosk

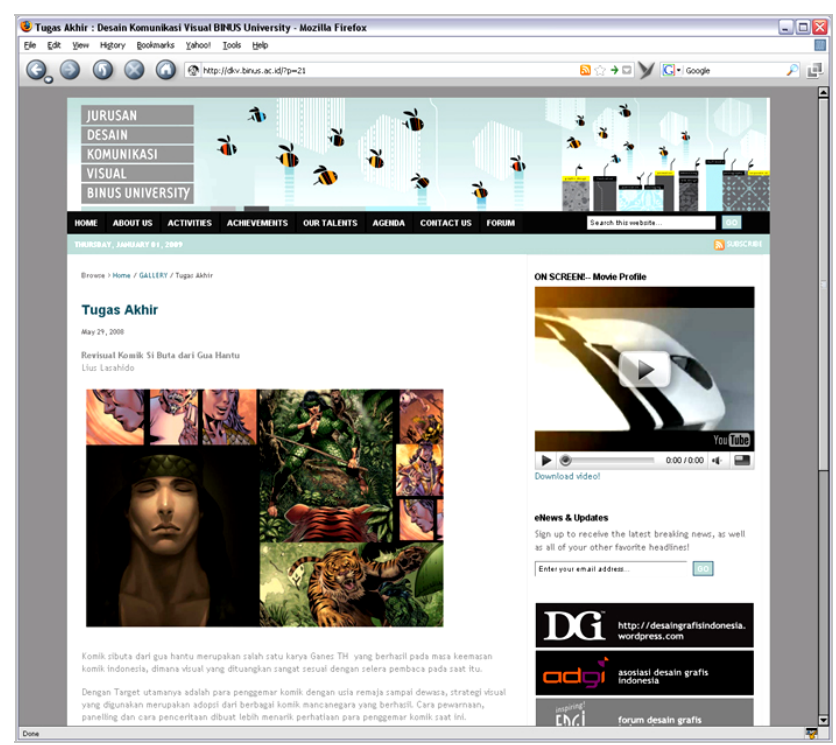

Gambar 17 Salah Satu Tampilan Halaman Dalam dari Situs DKV BINUS - Gallery

\section{Programming}

Tahapan yang dilakukan adalah Coding HTML/Flash, Scripting/Flash, Database, dan Content Management System. Tahapan tersebut dapat disederhanakan dengan pemanfaatan secara langsung engine Content Management System (CMS). Ada beberapa pilihan engine CMS dengan orientasi blog yang dapat digunakan seperti Joomla, Mambo, BlogSpot, Drupal, ExpressionEngine, TypePad; keputusan untuk menggunakan engine WordPress memiliki pertimbangan, yaitu (1) Free Software Open Source Software; (2) Mudah dalam instalasi dan operasional, terutama kemudahan dalam updating situs; (3) Kebutuhan standar instalasi sangat rendah; (4) Dilengkapi dengan fasilitas Spam Protection dan sistem password protected yang baik; (5) Fokus di dalam estetika, web standard dan 
kemudahan; (6) Menggunakan bahasa script yang "terbuka” (open source) hingga memungkinkan ditambahkan dengan plug-in, widgets, hingga dapat memaksimalkan fungsi dan kebutuhan dari situs; (7) Memiliki fasilitas user regristration dan multiple authors yang baik. Hingga memungkinkan pengelolaan berjenjang seperti pengelolaan media publikasi (koran, majalah); (8) WordPress berkembang dengan sangat pesat, dimulai pertama kali pada tahun 2003 dan pada tahun 2010 (versi 3.1), aplikasi mereka telah diunduh sekitar 25.000.000 kali.

\section{File Transfer Protocol Upload Site}

Secara konvensional memang membutuhkan tahapan ini, file situs yang telah selesai di-upload ke jaringan internet melalui fasilitas File Transfer Protocol. Namun, dengan penggunaan WordPress maka tahapan ini dapat dihilangkan. Pertama memang kita harus meng-install terlebih dahulu engine WordPress di server tempat di mana situs kita hosting. Setelah engine tersebut berjalan dengan baik maka kita tinggal meng-install theme yang kita pilih lalu setelah itu mengaktifkan situs lewat fasilitas wp-admin. Tahapan berikutnya kita tinggal mengisi web yang kita kembangkan. Termasuk bila kita ingin melakukan penambahan visual, plug-in, widget, scripting, semua dapat dilakukan secara webbased.

\section{SIMPULAN}

Situs institusi pada saat ini telah menjadi sebuah keharusan yang harus dimiliki. Banyak manfaat yang dapat dipetik apabila situs tersebut kita miliki, kita kelola dan dioperasionalkan secara maksimal. Bukan hanya manfaat yang bersifat komunikasi namun juga kita dapat memanfaatkan datadata statistik yang turut menyertai sebuah situs itu berjalan. Situs DKV BINUS yang beralamat di www.dkv.binus.ac.id adalah satu bentuk implementasi media yang diwujudkan. Tidak hanya manfaat informasi yang terpusat dapat dikelola melalui situs tersebut, namun juga proses dokumentasi yang terjaga, media marketing dalam berpromosi, dan salah satu yang tidak kalah pentingnya adalah sebagai media pusat keilmuan DKV. Bukan hanya mahasiswa dan dosen yang dapat memanfaatkan situs tersebut secara keilmuan, namun juga masyarakat umum, baik itu praktisi/profesional maupun para penyuka, pencinta serta pemerhati keilmuan DKV. Secara tidak langsung akan terjadi proses branding yang positif dengan menempatkan DKV BINUS sebagai pusat keilmuan DKV secara luas.

\section{DAFTAR PUSTAKA}

Burby, J. (2007). Actionable web analytics: Using data to make smart business decisions, Sybex.

Gene, De F. (2004). How to design a website. Retrieved November 10, 2008, from http://www.rocketface.com.

Graham, E. (2006). The good web site guide 2007: The completely revised, best-selling guide to over 5000 sites. United Kingdom: Harper Collins.

Jo Ann, T.H. (2007). Content management for dynamic web delivery, Wiley.

Julius, W. (2005). Web design: Best studios (icons), Taschen.

Kristen, C. (2007). Layout workbook: A real-world guide to building pages in graphic design, Rockport Publishers.

Pepin Press. (2007). Web design index by content 3. Pepin Press. 